\title{
What is a Green Economy? Review of National-Level Green Economy Policies in Cambodia and Lao PDR
}

\author{
Marketta Vuola ${ }^{1,2}$, Mika Korkeakoski ${ }^{3, *}$, Noora Vähäkari ${ }^{3}$, Michael B. Dwyer ${ }^{4}$, \\ Nicholas J. Hogarth ${ }^{2,5}{ }^{(D}$, Jari Kaivo-oja ${ }^{3}$, Jyrki Luukkanen ${ }^{3}$, Eliyan Chea ${ }^{6}$, Try Thuon ${ }^{7}(\mathbb{D}$ and \\ Keophousone Phonhalath ${ }^{8}$ \\ 1 Development Studies, Faculty of Social Sciences, University of Helsinki, 00014 Helsinki, Finland; \\ marketta.vuola@helsinki.fi \\ 2 Helsinki Institute of Sustainability Science (HELSUS), University of Helsinki, 00014 Helsinki, Finland; \\ nicholas.hogarth@helsinki.fi \\ 3 Finland Futures Research Centre, University of Turku, 20014 Turku, Finland; noora.vahakari@utu.fi (N.V.); \\ jari.kaivo-oja@utu.fi (J.K.-o.); jyrki.luukkanen@utu.fi (J.L.) \\ 4 Geography Department, Indiana University, Bloomington, IN 47405-7100, USA; mbdwyer@iu.edu \\ 5 Viikki Tropical Resources Institute (VITRI), Department of Forest Sciences, University of Helsinki, \\ 00014 Helsinki, Finland \\ 6 Department of Environmental Science, Royal University of Phnom Penh, Phnom Penh, P.O. Box 2640, \\ Cambodia; chea.eliyan@rupp.edu.kh \\ 7 Faculty of Development Studies, Royal University of Phnom Penh, Phnom Penh, P.O. Box 2640, Cambodia; \\ trythuon@gmail.com \\ 8 Environmental Engineering, National University of Laos, Vientiane, P.O. Box 7322, Lao PDR; \\ keophontahu@gmail.com \\ * Correspondence: mika.korkeakoski@utu.fi; Tel.: +358-44-33-33-275
}

Received: 13 July 2020; Accepted: 13 August 2020; Published: 18 August 2020

check for updates

\begin{abstract}
A green economy that simultaneously promotes environmental sustainability, social inclusiveness, and economic growth is expected to benefit the heavily resource-dependent least developed countries. Yet, internationally, there is very little empirically based research on how the "green development" agenda translates into natural resource management policies in the least developed countries. This paper examines the implementation of green economy policies at the national level in the energy and forestry sectors in the Lao PDR and Cambodia. Both countries have adopted green growth targets; however, in terms of natural resources management, two contradictory processes have taken place during the past decade. While there have been some initiatives to decentralize natural resource management by enhancing the role of local communities role, such as community-based forest or fishery management, the far greater trend has been the opening up of the economies of the Lao PDR and Cambodia to large-scale investments by multinational enterprises. Large-scale hydropower projects and increasing deforestation pose challenges to more sustainable natural resource management efforts. This article is based on an analysis of the national green economy strategies and expert interviews with the government, academia, private sector and international and national development organizations. Focusing on the energy and forestry sectors, but also analysing the national green economy strategies as a whole, our analysis sheds light on the choices made in the national development versus green economy strategies. While green economy thinking rests on strong state regulation, the policies are often formulated within a complex dynamic of donor and investor interests. The achievement of a green economy depends on the state; thus, it should steer investments to ecologically less harmful industries and ensure social inclusiveness in land-use decisions. Our results show, however, that implementing a green economy is far more complex. Despite the quest for synergies, at the sectoral level there are still many unaddressed trade-offs between, for example, energy sources and forms of land use.
\end{abstract}


Keywords: sustainability; green growth; green development; sustainable development; Lao PDR; Cambodia; energy; forest

\section{Introduction}

Emerging from the field of environmental economics, the concept of a green economy became the centrepiece of the United Nation's "Rio+20" conference in 2012, launching the green economy as the new buzzword in international policy discourse related to sustainable development. In its simplest expression, a green economy is low-carbon, resource efficient, and socially inclusive. In a green economy, growth in income and employment are driven by public and private investments that reduce carbon emissions and pollution, enhance energy and resource efficiency, and prevent the loss of biodiversity and ecosystem services [1]. Importantly, the green economy is presented as being able to generate as much, or even more growth as the current business-as-usual economy, albeit in a more sustainable and inclusive manner.

The green economy has a close link with the Brundtland Commission's sustainable development concept [2]. Sustainable development has so far been unachievable because, as argued by the proponents of a green economy [1,3], economies are biased towards securing growth by depleting natural resources. The United Nations Environment Programme's (UNEP) green economy report states that trade-offs are inevitable between environmental sustainability and economic progress, but fixing the failures in pricing policies and implementing regulatory changes that incentivize environmentally and socially sustainable economic development can provide opportunities for growth and employment [1]. The goal is to look for synergies, rather than trade-offs, and "recouple" environmental protection and economic growth $[4,5]$.

Green economy or green growth framing have been adopted by several international organizations in addition to UNEP. Green growth was brought into intergovernmental discussions for the first time at the United Nations Economic and Social Commission of Asia and the Pacific (UN ESCAP) Fifth Ministerial Conference on Environment and Development in Asia and the Pacific held in 2005 in Seoul [6]. The resulting Seoul Initiative on Environmentally Sustainable Economic Growth (Green Growth) frames green growth as a pre-requisite for building a green economy [7]. The Global Green Growth Institute (GGGI) was established to support and promote strong, inclusive, and sustainable economic growth in developing countries and emerging economies [8]. The World Bank adopted green growth as a way to improve living standards in developing countries in its report "Inclusive Green Growth: The Pathway to Sustainable Development", which calls for better measurement of economic performance that takes into account the value of natural capital [9].

Across the world, the adaptations of green economy to national economies and government agendas has resulted in very different forms. Death [10] distinguishes between four different green economy discourses: green resilience, green growth, green transformation, and green revolution. Green transformation and revolution discourses seek to challenge economic growth as the basis of our economies, while green resilience focuses on local community level resilience initiatives, which are seen as more technical, disregarding any need for a more fundamental change. Green growth is the most common form of green economy globally, and the most aligned with the mainstream neoclassical economic discourses. This is due to the focus on the opportunities of accumulation presented by techniques such as carbon markets, bio-prospecting, and commodifying ecosystem services, which are all means of "accumulation by conservation" (as termed by Büscher and Fletcher) [11].

What is common to all four discourses on green economy, and what contrasts them with sustainable development discourse, is the role of the state as the primary actor [10]. Green economy discourses-even the most revolutionary ones—can be interpreted as statist responses to the global financial and economic crises of 2007-2008 by re-legitimising public intervention in economic life. Indeed, the need for stronger government agency is at the centre of the reports of both UNEP and the World Bank [1,9]. Governments are expected to create enabling conditions in which investments could 
be redirected to industries that produce less greenhouse gas emissions, use natural resources more efficiently, and prevent environmental degradation by eliminating environmentally harmful subsidies, establishing greener standards for public procurements, stimulating investment, and correcting market failures. The call for such state intervention stems from the acknowledgement that the unregulated market will not correct itself towards a greener path on its own.

Concerns have been raised that in green economy thinking, economic growth is given priority over social justice and ecology, thus facing the similar pitfalls as sustainable development in attempting to balance between the three pillars of economy, environment, and society [12]. The green economy discourses escape the problem of trade-offs between environment and economic growth by arguing that the two can be decoupled, but this assumption has been challenged. For example, three recent studies [13-15] find no evidence for absolute decoupling to be possible. Relative decoupling can be achieved to some extent according to the studies; however, incorporating "rebound effects" in the models significantly decreases the likelihood. This is a noteworthy concern since increasing income can be expected to lead to more consumption of natural resources as lifestyles change [16].

Will the green economy be able fill its promise and fix the mismatch between economic growth and environmental degradation with state-led interventions, and how exactly will this be done? In this paper, we examine green economy development in two case countries, the Lao PDR and Cambodia, both of which are in the process of preparing their national green economy strategies. Using policy documents and key-informant interviews, we analyse the current stage of green economy development and attempt to shed light on how green economy is defined in these national contexts. With these examples from two least developed countries (LDCs), we aim to understand the various challenges of decoupling economic growth and environment while simultaneously striving to develop social wellbeing.

\subsection{Natural Resource Management in Cambodia and the Lao PDR}

In terms of natural resources management, Cambodia and the Lao PDR have both experienced contradictory pressures during the past decade. While international development organizations (e.g., UNEP, United Nations Conference on Trade and Development (UNCTAD) and United Nations Office of the High Representative for the Least Developed Countries, Landlocked Developing Countries and Small Island Developing States (UN-OHRILLS)) have encouraged initiatives to decentralize natural resource management, with communities having more control over the resources they depend on $[17,18]$, the economies of Cambodia and the Lao PDR and their natural resources have been opened up for large-scale investments and appropriation. Sustainable natural resource management policies are increasingly challenged by large-scale land concessions and investments of multinational enterprises, as well as by development projects that facilitate the possibilities of investments (e.g., infrastructure, mapping of natural resources, and reorganizing property rights) $[19,20]$. This development is relevant also in terms of the challenges presented by climate change, as the majority of rural communities depend directly on natural resources for their livelihoods. In the energy sector, current large-scale hydropower development may be justified as a low-carbon solution, but at the same time it is one of the main causes for diminishing fisheries and other aquatic resources, creating new vulnerabilities and reducing resilience to climate change [21-25]. Similar dynamics can be found in the forestry sector, which plays an important role in the national economies of both Cambodia and the Lao PDR, and in the livelihoods of rural and especially forest-dwelling communities by providing ecosystem services and non-timber forest products [26]. The main drivers of high rates of deforestation include conversion to agricultural land and plantation crops (including timber trees and rubber), as well as mining and infrastructure development, including hydropower [26]. This again increases land conflicts and vulnerabilities in the face of climate change [19]. 


\subsection{Green Growth Mechanisms: Applying the Green Economy in the Global South}

The UNEP presents LDCs like Cambodia and the Lao PDR as being well-positioned in the transition to the green economy due to their low-carbon profile and rich natural capital and cultural assets [17]. According to a joint publication by the UNEP, UNCTAD, and UN-OHRLLS, LDCs are free from the infrastructural lock-ins on polluting technologies and therefore have the opportunity to jump-start their transition towards a green economy (i.e., leapfrogging) while sustainably utilizing their vast natural resources [17]. To achieve this in practice, proponents argue that investments should be targeted at sectors including renewable energy, agriculture, forestry, tourism, and enhanced ecosystem services, i.e., the sectors most relevant to the livelihoods of the poorest segments of society and in which sustainable practices already exist, such as those related to community-based forestry [17]. Development in these sectors should theoretically drive job creation, empower low-income populations and contribute to achieving sustainable development, while green economy instruments also offer new sources for external development funding [17]. Regarding investments, the emphasis should shift from quantity to quality, thereby preventing the current shortcomings in the transparency in granting of concessions, assessment of environmental and social impacts, and consultation with local people $[19,23]$. This requires the states to take a leading role in strengthening the investment and environmental management systems [10].

Various mechanisms have been established by international organisations to operationalise green economy transitions in LDCs. In particular, the emerging markets of ecosystem services and carbon offsets provide market driven incentives that are expected to benefit LDCs [17]. Mechanisms for carbon offsets developed by the United Nations Framework Convention on Climate Change (UNFCCC) include the Clean Development Mechanism (CDM) and reducing emissions from deforestation and forest degradation (REDD+). The CDM and Voluntary Emission Reduction (VER) schemes promote ways for industrialised countries to offset their carbon emissions through buying carbon credits. Similarly, REDD+ was established to create financial value for the carbon stored in forests by offering results-based payments for developing countries for actions to reduce deforestation and forest degradation and enhance conservation and sustainable management of forests [27]. On top of market-based programs, green economy rests on a variety of state initiatives including environment-related infrastructure expansion (e.g., water, renewable energy, and green transportation), "climate-smart" agriculture, micro-insurance, cash transfers, and community forestry expansion [10]. Mechanisms such as the European Union's Forest Law Enforcement, Governance and Trade (EU FLEGT) [28] aim to improve the state regulatory capacity in specific sectors.

In this article, we aim to analyse how Cambodia and the Lao PDR are incorporating these various green economy mechanisms in their national development plans, and whether they seem likely to provide the shift to a more environmentally sound and socially inclusive economy and address the vulnerabilities created through the large-scale investments and land appropriation.

\section{Materials and Methods}

This research paper is based on a desk review of the key national green economy/green growth-related documents (Table 1). In Cambodia, we analysed the National Policy on Green Growth (NPGG) 2013-2030 [29], the National Strategic Plan on Green Growth (NSPGG) 2013-2030 [30] and the National Strategic Development Plan (NSDP) 2014-2018 [31]. In the Lao PDR, we analysed the Lao PDR's 8th Five-Year National Socio-Economic Development Plan (NSEDP) 2016-2020 [32], the Lao PDR First Programmatic Green Growth Development Policy Operation [33], and the first draft of the new National Green Growth Strategy of the Lao PDR [34]. The purpose of this analysis was to examine more closely the underlying definition of "green economy" in both countries. We examined this by focusing on a few guiding questions: What are the main goals set for the strategies? With what kinds of policies and targets do the strategies strive to reach the key goals of green economy: social inclusiveness, carbon reduction, and resource-efficiency? What implications may we expect the strategies to have at the national level, and will they be in line with the green economy discourse? Finally, to understand 
the difficult task of dealing with trade-offs, we examined more specifically the energy and forestry sectors and the priorities, policies, and targets that the strategies set for them.

Table 1. Reviewed documents from the Lao PDR and Cambodia.

\begin{tabular}{ccc}
\hline & Cambodia & Lao PDR \\
\hline National Development Plans & $\begin{array}{c}\text { National Strategic Development } \\
\text { Plan (NSDP) 2014-2018 }\end{array}$ & $\begin{array}{c}\text { National Socio-Economic Development Plan } \\
\text { NSEDP (2016-2020) }\end{array}$ \\
\hline $\begin{array}{c}\text { Green Economy/Green } \\
\text { Growth Policies }\end{array}$ & $\begin{array}{c}\text { National Policy on Green Growth } \\
\text { (NPGG) 2013-2030 }\end{array}$ & $\begin{array}{c}\text { Lao PDR First Programmatic Green Growth } \\
\text { Development Policy Operation }\end{array}$ \\
\hline $\begin{array}{c}\text { Green Economy/Green } \\
\text { Growth Strategies }\end{array}$ & $\begin{array}{c}\text { National Strategic Plan on Green } \\
\text { Growth (NSPGG) 2013-2020 }\end{array}$ & \begin{tabular}{c} 
National Green Growth Strategy (NGGS) (draft) \\
\hline
\end{tabular} \\
\hline
\end{tabular}

In order to understand the institutional contexts to facilitate the desk review, the research team conducted 48 key informant interviews between February 2016 and September 2018 with national and international actors relevant to green economy in the Lao PDR, Cambodia, and the Mekong region. Insights were provided by experts from government institutions, universities, private sector and international development organisations, and networks. We followed a qualitative, semi-structured, open-ended and in-depth interviewing method and thematic data analysis method. Shedding light on the various stakeholder perspectives, we used the interview data as contextual background for our review, in particular on the institutional settings in which the preparation of the policy documents had taken place.

\section{Results: Greening the Economies of Cambodia and the Lao PDR?}

\subsection{Cambodia}

\subsubsection{Institutional Setting and History of Green Economy in Cambodia}

Natural resource management policy is often linked to contested power relations, and in particular to the survival strategies and capacity of the institutions involved to cope with changes both internal and external $[35,36]$. In Cambodia, the Ministry of Environment (MOE), since its early establishment in the late 1990s/early 2000s, has played a central role in natural resource governance. However, since natural resources provided a lucrative source of economic growth, the mandate of MOE to protect and conserve natural resources became weaker. By the late 2000s, the emerging concern of climate change and popularity of green growth helped the ministry to gradually regain its position as the focal ministry responsible for climate change and green growth [37].

In 2015, the newly appointed minister started a reform process within MOE to consolidate institutional management with clear roles and responsibilities. One of the key priorities was to better coordinate the programs and institutions working for green growth, climate change, integrated water resource and sustainable natural resource management [38-40]. This process, backed up strongly by the international development community, addressed three aspects:

(1) The ministry's mandate was redefined, setting key priorities and sectors. The reform aimed to identify opportunities for sectors to better respond to natural resource management and climate change. The role of conservation and production was clearly separated between the MOE and the Ministry of Agriculture, Forestry and Fisheries (MAFF).

(2) Environmental governance reforms were initiated, promoting the upgrade of Environmental Impact Assessment (EIA) from sub-decree to a law and drafting a more comprehensive legal framework, the "Environment and Natural Resource Code". The current draft of the code aims to provide guiding principles for sustainable development and serves as the key legal framework for environmental planning and management in all developments. Furthermore, Strategic Environmental Assessments (SEA), EIAs, and Climate Vulnerability Assessments are mentioned in the Code as guiding tools 
for decision-making. Integrated ecosystem mapping is also being developed in collaboration with development partners and the ministry for more informed decision-making.

(3) The National Council for Sustainable Development (NCSD) was created by merging two former institutions: the National Committee for Climate Change and the National Council of Green Growth [38]. It was officially established with the mission to promote sustainable development in Cambodia and to ensure balance between economics, environment, society and culture. The NCSD is hosted by MOE and chaired by the Prime Minister with 34 members from line ministries and 25 governors of Capital-Province's governing bodies. It has a general secretariat under MOE, an independent budget, and the right to receive and manage budgets from development partners and other sources [39] (Figure 1).

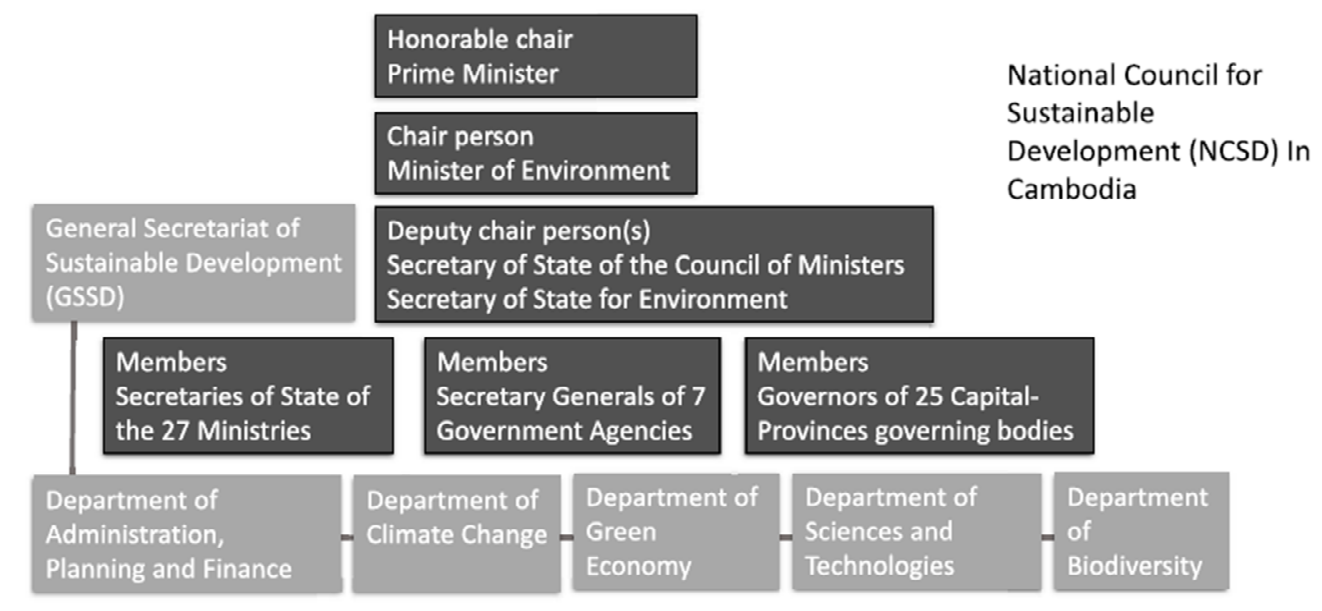

Figure 1. Organizational structure of the National Council for Sustainable Development of Cambodia.

In the transition toward a green economy, Cambodia faces many challenges, particularly in terms of the capacity of the institutions and their staff, as well as the availability of information for planning and inter-ministerial decision-making, as stated by our interviewees. Land use planning and natural resources management in particular require national-level integrated ecosystem mapping and spatial data from government and non-governmental sources. The current draft of NSDP 2019-2023 (at the time of writing there was no English translation of the plan available) should guide MOE and NCSD in capacity development and technical support towards more sustainable development [40].

\subsubsection{Definition of Green Economy in Cambodia}

Cambodia was one of the first countries to start developing a roadmap towards a national green growth policy in 2009, backed up by the GGGI, proposing various short, medium, and long-term pathways to a green economy, and highlighting the importance of access to renewable energy and sustainable land-use. As a continuum, the Cambodian National Strategic Plan on Green Growth (NSPGG) 2013-2030 [30] and the National Policy on Green Growth (NPGG) 2013-2030 [29] were published in 2013. The strategy is in effect up until 2030, and is coordinated by the NCSD.

The NSPGG broadly incorporates nine sectors, namely green investments and green job creation, green economic management, blue economy, green environment, and natural resource management, human resource development and green education, effective green technology management, green social safety system, protection of green cultural heritage and national identity, and good governance of green growth. The green growth paradigm is to be incorporated sector-wide in the national development efforts by 2030. The NSPGG aims to mainstream green growth thinking into national development plans in Cambodia and thus boost wellbeing and economic growth for poverty reduction.

To realise the targets of NSPGG, green growth is addressed as a cross cutting policy in the National Strategic Development Plan (NSDP) 2014-2018 [31]. Its strategic objective is to maintain an open 
market economy, and well-formulated policies towards sustainable, low carbon, and resilient modes of development where a green growth agenda is highlighted [31]. To achieve this, the plan also suggests the country needs to expand and restore forest-cover to become a net carbon creditor country, restore and maintain freshwater and marine stocks, and prevent degradation of soil, water and air quality. In cross-sectoral action, the plan suggests to adopt the national strategic plan (NSPGG) and policy (NPGG) on green growth to serve as guidelines for line ministries and respective sectors.

The National Policy on Green Growth (NPGG) is responsible for setting forth the action plan for all the listed strategic directions together with a monitoring and evaluation plan, and indicators for target measurement.

As the Strategic Plan on Green Growth acts primarily as an orientation paper, it has listed tens of projects or development targets and indicative entities or ministries in charge of implementation under each focus sector. The proposals vary from niche to broad. For instance, the Ministry of Tourism should create eco-labelling for tour companies (niche), but the Ministry of Commerce should change to start using green technological solutions in all sectors (broad). The lack of concrete policy recommendations as well as targets and indicators to monitor the performance of the 153 outlined actions spread among multiple entities in the strategic plan gives each entity a responsibility to determine the details of the actions themselves. The strategy aims for a comprehensive sector-wide sustainability guideline and string of proposals.

The essence of the green growth strategy and policy is in transforming the conventional economic development into a more sustainable growth that can help lead Cambodia to developed country status. Business based on natural resource use is seen to improve towards more responsible practices through Social Impact Assessment (SIA) and EIA processes, and the strategy proposes "polluter pays" and "reduce, reuse and recycle" principles to encourage more efficient resource use together with a "sustainable production and consumption" framework [30] p. 6. The NSDP (2019-2023) will guide the next steps and national priorities for Cambodia [40].

\section{Energy}

Due to dependency on imported electricity and insufficient domestic production, Cambodia has among the highest prices in the region, while only some $50 \%$ of the population have access to electricity [41]. Due to rapidly growing demand and hopes for enhanced energy security and affordability, investments have been targeted mainly on large-scale hydropower and coal power plants, causing debate around environmental and social impacts in the vulnerable Mekong River basin.

The NSPGG does not highlight energy as one of the nine "strategic directions", but discusses it under different actions and under "Management of green environment and natural resource management". Under green investments and green jobs, it states that reduction in energy and natural resource use will be achieved through sustainable investments. "Green industry" and "green construction" encourage the use of renewable energy, energy savings and efficiency, and effective use of raw materials [30]. Such investments are attracted through, for example, different meriting systems such as "green flag", "green merit" or "green certificate". Energy efficiency and renewable energy are mentioned in the NSPGG promoting resource efficiency and the use of modernised technologies. Sustainable water resource management is understood as access to fresh water for drinking and sanitation, irrigation for agriculture, and improved wastewater treatment systems, but altering natural river flows due to large-scale hydropower development remains unmentioned.

The NSPGG states in its recommendations and description: "Efficient fossil fuel consumption and natural gas usage for the long term can effectively provide supplies to huge towns and the RGC's (Royal Government of Cambodia) improving efficient usage of electricity-generating factories run by coals for the long term shall reduce environmental pollution and greenhouse gas emission from these electricity factories" [30] (p. 14). In short, the strategy does not question Cambodia's dependency on coal but aims for a more "sustainable and efficient use" of fossil fuels. Similarly, it does not acknowledge the environmental and social problems associated with large-scale hydropower development in the 
country [42-44]. The NSPGG promotes an increased uptake of rural renewable energy solutions mostly in terms of conventional biomass use, disregarding other options such as the abundant solar energy resources [45-47].

\section{Forests}

The forest concession system in the 1990s and consequential legal logging and illegal confiscation have resulted in a significant decrease in forest cover and biodiversity in Cambodia [37,48]. The Forest Law [49], which distinguishes between production forests (available for economic land concessions), protected forests, conversion forests (role not yet distinguished), and privately owned land (land use type dependent on the owner), has not been able to stop the degradation process. Acquisitions and illegal logging have increased at an alarming rate, which is among the fastest in the world [50,51]. Forest loss is critical, and negative consequences could potentially multiply due to climate change in a country where $80 \%$ of the population live in rural areas and are highly dependent on natural resources for their livelihoods [52]. In response, in 2016 the government took steps to decrease the economic land concession titles from 99 years to 50 years, and to transfer Economic Land Concessions (ELCs) into social land concessions [53]. Additionally, the government has formulated, with assistance from UNDP, a Production Forest Strategic Plan 2018-2032 to improve the sustainable management of forests for economic use to prevent deforestation.

The value of sustainable forest use and protection for poverty reduction, enhancement of local economies and food supply is also noted in the NSPGG [30]. However, the government efforts to prevent illegal logging and timber trade are barely mentioned. Similarly to energy, sustainable natural resource use is outlined in multiple strategic directions and actions, but a comprehensive orientation to sustainable forest use alone is missing. Actions related to forests include green agriculture promoted in protected areas, although the ways that this is implemented or the resulting benefits are not described [30]. An updated land use registration and categorization is also suggested, distinguishing between productive areas, community development zones, protected forest areas and watersheds, and protected community areas. According to the strategy, this should both encourage investors in concessional lands as well as ensure sustainable forest product use and protection [30]. A legal framework for Payments for Ecosystem Services (PES) has been developed with the aim of ensuring the country's ability to benefit from market-based green economy funding. Furthermore, carbon crediting is suggested as a means to implement policies for the sustainable use of natural resources [30].

\subsection{Lao PDR}

\subsubsection{Institutional Setting and History of Green Economy in the Lao PDR}

In the Lao PDR, the present-day configuration of green economy reflects the institutional history and struggles over natural resource governance that have been central to internal Lao state politics since the 1990s, and that have been the target of World Bank reforms since at least the early 2000s. This history is best understood through two developments: the Nam Theun 2 hydropower project (NT2) and the establishment of the Ministry of Natural Resources and Environment (MONRE). The NT2 project was an effort by one of the funders, the World Bank, to "turn the resource curse on its head" [54] p. 34. This was done through institutional reforms, namely the issuing of a Prime Ministerial decree on compensation and resettlement and the passage of the Environment Law, in 2005. The Prime Ministerial decree formalized the compensation process for development projects, providing a regulatory umbrella for NT2, which was then expected to ripple out to other sectors of the economy and other projects in the energy sector. The Environment Law did the equivalent for environmental impact assessment (EIA), providing a legal framework for the intended standardization of the EIA process across multiple sectors [55].

These reforms were mirrored in the creation of new institutions for enforcement. The body most closely associated with NT2 was an environmental regulator called the Science, Technology and 
Environment Agency (STEA), which, in 2011 was combined with the National Land Management Agency (NLMA) to create a new ministry: MONRE. Created in 2004-2006, the NLMA was mandated to inventory land concessions that had been approved by various ministries and levels of government, highlighting the fragmentation of authority at the time over natural resource governance [56,57]. However, despite the legal mandate of NLMA to consolidate the regulation of "development projects", a number of state actors-notably provincial governors and the ministries of Agriculture and Forestry, Public Works, and Defence-resisted the centralization of oversight, and continued to approve new projects and defend their earlier regulatory prerogatives $[20,56]$. In this light, these current efforts to bring the agriculture, forestry and hydropower sectors under the umbrella of green growth planning [33] need to be seen within this longer history to consolidate power through administrative centralization and formalization [58].

Currently, inter-ministerial coordination takes place through the Green Growth National Steering Committee (GGNSC), consisting of representatives from several ministries (MONRE, MAF, MEM, and the ministries of Industry and Commerce, and Public Works and Transportation) and mandated to lead and oversee the country's green growth agenda [33] (Figure 2). The National Economic Research Institute (NERI) and Department of Planning are currently finalising the national Green Growth Strategy proposal, and the work is funded by the World Bank. This illustrates that, as government funding for these activities is very limited, the implementation of green economy depends on external funding from development partners. On top of the inadequate financing, our interviewees cited important obstacles to green economy development at the institutional level, for example in working practices of cross-sectoral collaboration and coordination. It is hoped that such obstacles will be ameliorated in the future by the Green Growth Centre that is being designed by the Ministry of Planning and Investments to support the ministries' work in "greening" the sector activities.

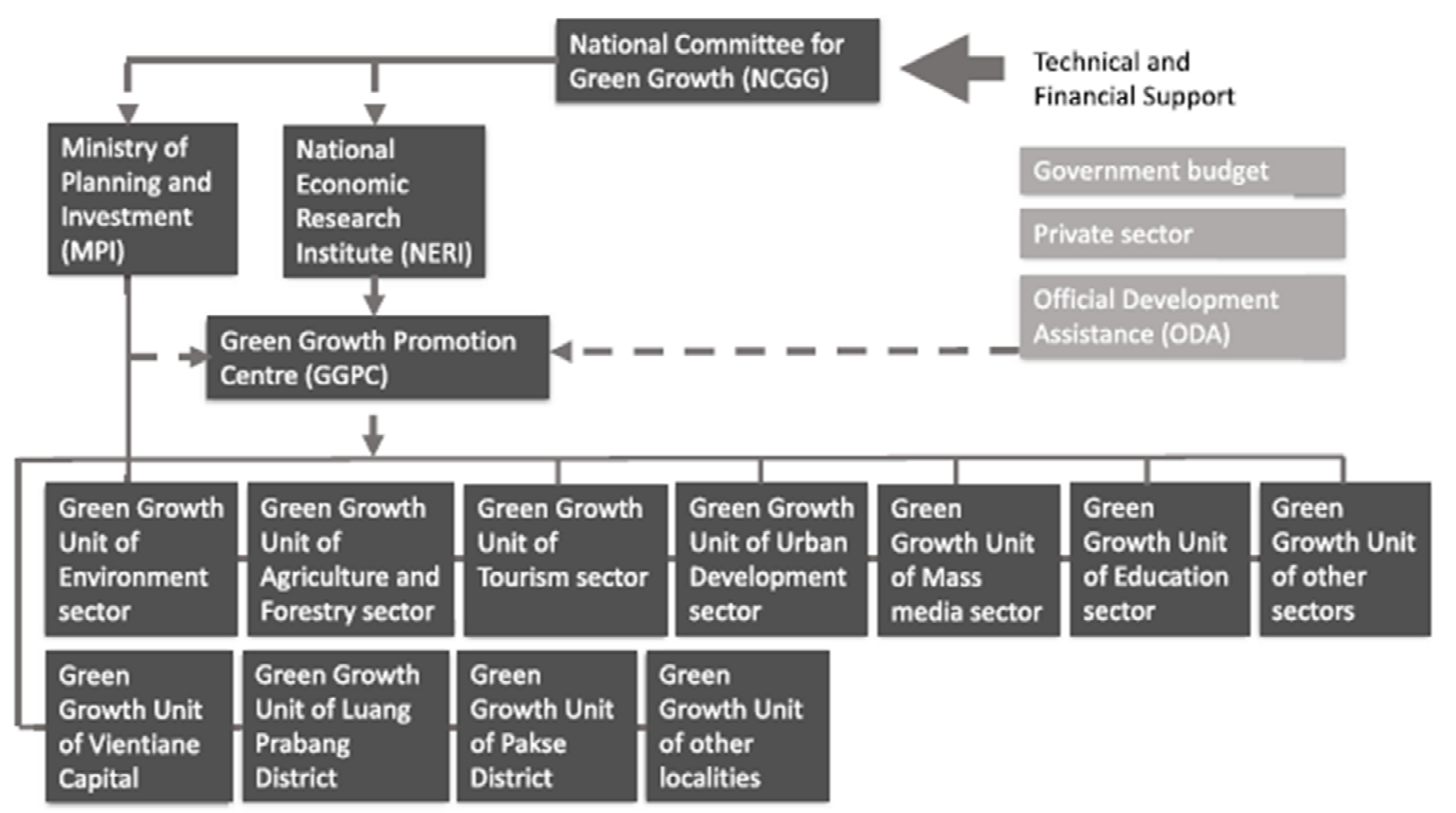

Figure 2. Organizational structure for promoting the implementation of green growth strategy until 2025 in the Lao PDR.

\subsubsection{Definition of Green Economy in the Lao PDR}

The World Bank funded Green Growth Policy Development Operation in the Lao PDR frames green growth as a route to graduating from LDC status: "Lao PDR is aiming to undercut a high-impact growth path and leapfrog to brand the nation as "Green, Clean, and Beautiful Lao PDR" [33] p. 10. According to the National Green Growth Strategy (NGGS), the government of the Lao PDR has 
endorsed green growth as an overarching framework and included it in the country's larger sustainable development agenda [34]. The 8th National Socio-Economic Development Plan (NSEDP) includes green inclusive growth as one of the priority themes with half of its indicators harmonized with Sustainable Development Goals and green growth goals. Outcome 1 of the 8th NSEDP sets the goal of continued, firm and inclusive growth emphasising also the improvement of the quality of investment by implementing policies to reduce environmental degradation [32]. The track to environmentally sustainable growth is further supported in Outcome 3 which states that "natural resources and the environment are effectively protected and utilized according to green growth and sustainable principles" [32] p. 89. The NGGS is defined as a tool to achieve these targets [34]. The first draft of NGGS sets six focus sectors, including forestry and energy, and five cross-sectoral focus areas including: (1) strengthening the investment management system to ensure green growth, (2) scientific, policy, and technological research, (3) strengthening the environmental management system, (4) promoting green lifestyle and consumption, and (5) green growth and gender equality in the Lao PDR [34].

The first draft of the NGGS frames green growth as an opportunity and a condition for the country to receive grants and low-interest loans from international organizations, banks, and other countries [34]. The government will encourage foreign and domestic investments by, for example, creating enabling conditions as well as providing facilities and minimum revenue guarantees. Following the donor rhetoric, the first output of the 8th NSEDP states that "strategies for privatization and the attraction of investments need to be underpinned by transparent enforcement of legislation, rules and regulations ensuring that diverse investors are attracted and that Lao citizens will benefit from investments and the privatization of state enterprises, land, etc." [32] p. 94.

The World Bank describes its assistance to the Lao PDR for Green Growth planning as an effort to correct the Lao PDR's high-growth but low-development trajectory by making resource use more efficient, less harmful, and more sustainable, and to correct the country's high debt loads [33]. The World Bank's support project attempts to integrate environmental and social considerations into planning under a regulatory umbrella of impact assessment. This includes a policy requiring a SEA at the sectoral level for policies, programs and strategic plans. In practice, SEA guidelines are still at their initial stages as the Lao government put the policy forward only three months before the publication of the project document [33]. To minimise the harmful impacts of individual investment projects, a new decree for Environmental and Social Impact Assessment (ESIA) is still being developed. In the draft NGGS, the first cross-sectoral focus area of strengthening the investment management system involves the improvement of several natural resource and land-use related laws, upgrading several Prime Ministerial decrees into laws (including decree 112 on EIA), "greening" public procurement, and building the central and provincial government capacity of EIA implementation [34].

Outlining the plans on social inclusivity, the World Bank funded document argues that poor people will benefit from green growth through enhanced macroeconomic stability, decreased environmental risks, and job creation in new industries such as tourism [33]. The social and distributional considerations were foreseen to be designed and included in the "next stage of policy reforms" [33] p. 31. The poverty and social impact analysis of the policy operation showed that because natural resources are critical for livelihoods of the poor there will be measures taken to recognise traditional rights, the value of natural resources, and enhance participatory natural resources management [33]. These measures, however, were not mentioned in the policy tracks. Moreover, very few of the mentioned social inclusion measures made it into the draft NGGS. It includes the overall goal of "Ensuring the reduction of poverty, social inequality, gender role; and improving the quality of the living conditions of the people" and monitors its achievement using poverty rates and GINI indices as well as several gender and education related indicators [34]. However, reduction of poverty and social inequalities are not among the focus areas and thus there are no clear priority actions and intermediate goals. Job creation is discussed mainly in the tourism sector, and the indicator set to measure this progress is the percentage of revenue from tourism in the GDP, which only indirectly tells about the employment impacts. On the other hand, the strategy foresees that the decreases in labour intensity 
in the agriculture sector will require some farmers moving to other professions [34]. The agriculture sector is by far the biggest sector currently providing employment in the country, but the foreseen change is not reflected in a policy of creating alternative employment for farmers.

\subsubsection{Energy}

The energy sector has developed rapidly in the Lao PDR. Large-scale hydropower has been heavily invested in and energy exports to neighbouring countries have driven the fast economic growth [59]. Half of the primary energy consumption in the Lao PDR continues to be based on biomass while the other half consists of imported oil, charcoal, coal, and electricity, which is almost solely produced by hydropower plants [60,61]. The household electrification rate rose from $72.5 \%$ in 2010 to $80.3 \%$ in 2016 among the rural population, and to $97.4 \%$ among the urban population mainly through grid expansion. The national target for 2030 is set at $98 \%$ [61,62].

Both the draft NGGS and the 8th NSEDP provide sectoral targets and focus areas for greener pathways, although they controversially define hydropower as a subset of "clean and environmentally friendly energy" (e.g., "allow the people (throughout the country) to access and use clean and environmentally-friendly energy (hydro-electricity)" [34] (Section 2.2.1 part 5)). The stated target is to increase the percentage of "clean" energy (defined as hydro-electricity, solar energy, and wind energy) to $40 \%$ by 2030. The national Renewable Energy Strategy (2011-2025) implies that the targets for non-large-scale hydro are not very ambitious: wind energy is to be increased to $73 \mathrm{MW}$, solar to $106 \mathrm{MW}$ and small hydropower to $400 \mathrm{MW}$ [63]. Meanwhile the 8th NSEDP sets priority actions to complete 15 large hydropower dams, "such as Sayabouly Dam with installed capacity of 1285 MW (2019), Xe Pien-Xe Namnoi with installed capacity of 410 MW (2019), Sekhamane 1 with installed capacity of $322 \mathrm{MW}$ (2016)" [32] p. 95. Contrary to much of the scientific research and public sentiment in the region [64-66], the three policy documents fail to discuss the sustainability aspects of hydropower, although the World Bank supported document mentions stakeholder engagement in river basin management planning under the Integrated Water Resource Management [33].

The draft NGGS does not discuss coal for energy production at all in its current form, but only touches on the topic when arguing for hydropower development as a way to reduce the use of energy from firewood, coal, charcoal fuels, and others [34]. The 8th NSEDP, however, states the aim to continue the construction of a coal-based energy generation plant in the Southern region while also somehow ensuring "national energy to be sustainable, aiming at ensuring power stability for domestic use (hydropower, charcoal) and being competitive in the region" [32] p. 121.

\subsubsection{Forests}

The draft NGGS describes the forest as a "source of food, water for consumption and for the agricultural production of the Lao people of various ethnic groups and ... also the source of carbon retention" [26] (Section 2.2.1). Around 40\% of the Lao PDR's land area is covered by closed canopy forest that is degrading rapidly. In the period of 1990-2015, primary forest area decreased $25 \%$ while planted and naturally regenerated forests increased [26]. The draft NGGS identifies wood exports, land concessions of industrial tree plantations, and various development projects as causes for deforestation, but does not mention illegal logging [34]. Illegal timber export, mainly to Vietnam and China, were found by WWF to be more than ten times the official timber harvest in the Lao PDR in 2013, having grown exponentially since the end of 2000s [67]. The forestry targets of NGGS include ending the export of wood and semi-finished wood products with low value, increasing natural forest cover from 40 up to $70 \%$ of the country's total land area by 2030, and increasing conservation forest areas. While government efforts have increasingly targeted illegal logging enforcement over the last few years, scepticism remains widespread about the prospects for regaining $70 \%$ forest cover.

The priority actions of the 8th NSEDP are mostly aimed towards more efficient forest management and use while also supporting community-based forest management [24]. The draft NGGS does not mention community-based forestry but aims to develop financial mechanisms, such as REDD+, 
for protecting the national and local conservation forests. From the early 2000s up to 2012, policy emphasis was placed on attracting large-scale plantation investors through a state land concession approach $[28,30]$. The draft NGGS acknowledges that historically "granting of land concessions and the investment in this sector [wood plantations] has not generate reasonable economic benefit to the country" [26] (Section 2.2.1). The NGGS therefore aims at restricting or ending the granting of concessions for industrial tree plantations, now favouring alternatives, such as participatory company-community partnerships and outgrower schemes [68]. Companies, such as Stora Enso Laos, Burapha Agroforestry, and Mekong Timber Plantations Company, are exploring options with the Government of Laos to operate under these frameworks. As Barney and van der Meer Simo conclude: "The challenge for the Lao government is to develop a policy framework that facilitates high quality and responsible corporate investment in the plantation forestry sector, and to support smallholder and household enterprise, while providing clear guidance on company-community participation and benefit-sharing arrangements" [68] p. 10.

\section{Discussion}

Our analysis attempts to shed light on the paths which Cambodia and the Lao PDR are currently about to take on green economy development. We first look at the energy and forestry sector policies and provide some recommendations to improve the plans in these sectors. We then examine the larger framing of the green economy and the prospects for its implementation at the national level.

\subsection{The Energy Sector}

In the energy sector plans, the Lao PDR and Cambodia are embracing a wide variety of energy technologies, but the plans are dominated by large-scale hydropower and coal power development. Large-scale hydropower is strongly promoted both in the draft NGGS and other national development plans in the Lao PDR. In Cambodia, hydropower is not mentioned in the documents we reviewed, yet large-scale hydropower development dominates domestic power development plans. The Association of Southeast Asian Nations (ASEAN) and international banks define large-scale hydropower as a renewable energy source that consequently could fit under the umbrella of green economy [69], but the external impacts and large emissions from reservoirs and deforestation question its sustainability unanimously [64]. In terms of coal power, efficient use of fossil fuels such as "clean coal power" are listed as "green" energy in Cambodia [30]. In the Lao PDR green economy documents, coal power is not addressed, but the recent development of, e.g., the Hongsa coal fired power plant in 2015 and potential other coal power plants question the de-carbonization targets of the energy sector [70]. The conclusion seems to be that in order to receive public-sector financing, the two countries are forced to frame their large-scale hydro and coal power plans as a part of green economy, stretching the rhetoric to the breaking point.

The increasing share of renewables is mentioned in the green economy strategies of both countries, but detailed targets for different renewable energy shares, mechanisms, and the needed regulatory improvements are largely missing. Compared to the targets of coal and large-scale hydropower, the intentions seem weak. The choice of energy sources reflects the more fundamental questions of green economy in prioritization between growth and sustainability targets. As pointed out by Vazques-Brust et al. [4], green economy transition inevitably requires phasing out some environmentally harmful industries, and therefore, a gradual phasing out of the energy sources, including fossil fuels, and large-scale hydropower, that have significant negative environmental and social impacts.

To encourage the development of renewable energy, new regulatory frameworks, targets, incentives, and enabling environment for clean, sustainable energy production should be set simultaneously supporting local and regional sustainable energy production. During the process of phasing out the conventional large-scale energy projects, the legislation and procedures of ESIA should be strengthened, and benefit-sharing mechanisms developed to minimise negative impacts and guarantee public benefits, especially to communities directly affected from large infrastructure 
projects, such as dams. Our recommendation is to implement realistic energy demand scenarios and growth targets and (re)analysing the external (environmental and social) costs and benefits of regional energy/electricity export markets within the ASEAN region to ensure optimal investments; this also means avoiding over-investment or under-investments in critical energy infrastructures.

\subsection{Forest Sector}

Both Cambodia and the Lao PDR emphasize the roles of forests in green economy. The dissatisfaction towards the poor economic benefits of large-scale wood plantations can be seen especially in the Lao PDR's strategy, where the state aims to increase the domestic added value from the export of wood products. Here, programs such as EU-FLEGT can provide assistance in the certification and setting up regulatory frameworks for the use of timber.

In terms of the natural forest cover, the targets are ambitious given the current support mechanisms: in the Lao PDR, 70\% by 2030 according to their green growth strategy, and in Cambodia, $60 \%$ by 2030 according to the country's nationally determined contribution to the reduction of greenhouse gases at the LULUCF (land use, land use change and forestry) sector [71]. Enforcement capacities and resources to safeguard forests in both protected and production forests are already limited, and the expansion of protected areas will be a challenging task without proper financing mechanisms. Here, REDD+ and other PES schemes may be one of the potential funding channels, but alone will not be comprehensive in achieving the targets. Furthermore, the ways in which such programmes are set up or scaled up are not explained in the strategies. The markets of ecosystem services and carbon offsets may emerge as a new arena of tensions in integrating climate policies, natural resource policies, and poverty reduction. While they are assumed to be relevant green growth options for LDCs, REDD+, and CDM have received wide criticism for falling short in climate mitigation and forest protection, or contributing to sustainable development more generally [72,73]. Markets of ecosystem services and carbon offsets offer new commodities and opportunities for commercialization and market integration, but have in many cases led to land and water grabbing and displacement [11]. Therefore, the participation of local communities in drafting climate and forest related strategies is an extremely important point of focus in both Cambodia and the Lao PDR, implying also the recognition of local tenure rights. Thus far, both look forward to using market-based tools as a way to finance conservation efforts, yet leave the considerations of local communities unaddressed. Both Cambodia and the Lao PDR are also restructuring the categorisation of their forest areas from different forms of protection to types of production forests with varying levels of authorised community or business presence. In these shifts, mechanisms ensuring the quality of investments and regulation on company-community relations need to be implemented with utmost care.

\subsection{Definition of Green Economy in Cambodia and the Lao PDR}

In both of our case countries, the international development partners such as the World Bank have influenced the definition and design of national strategies through advising and funding the strategy development [33]. Consequently, the national strategies can be criticised along with the same shortcomings as the World Bank agenda in general; i.e., the ambiguity between the concepts of green economy and green growth, uncritical trust in economic growth, and being too aligned with the current economic systems [74,75]. Both of our case countries have adopted the green growth discourse, which is the dominant form of green economy worldwide [10]. Within this context, an attempt to find synergies between environmental considerations and growth can be found in the national green growth strategies in both countries. On environmental matters, the argument goes that the "greener" economic activities can support economic growth through, for example, resource efficiency, greener image to attract tourism, and markets for "cleaner" agricultural products [25]. Environmental sustainability may not be the first priority but targets (e.g., increasing forest cover), funding mechanisms (e.g., CDM, REDD+), and legislative changes (e.g., mechanisms such as SEA, EIA, and principles such as "polluter pays") are proposed that could potentially have significant positive impacts on 
the environment. Improving the quality of investments is emphasised as a key focus area of green economy in both countries. The eventual effectiveness of impact assessment tools depends on the level to which they are able to carry out their function of preventing permits for low quality projects in the context of potentially contradictory targets among the government agendas (e.g., related to mining and hydropower). Ensuring that stakeholder voices are heard, especially those of local communities, in the ESIA process will need immense improvement in both countries that, to date, have not protected their population from destructive impacts of large-scale investment [23].

Georgeson et al. [74] suggests that the lack of differentiation between green growth and more radical green economy transformations may be strategic; as governments are sceptical of abandoning the conventional growth model, World Bank, and UNEP are trying to promote the green economy, which does not have to signify a radical change in paradigm [76]. The green economy reframes the discourse from a negative debate about constraints into a positive one about opportunities and attempts to create policy frameworks to correct environmentally harmful market and policy biases [74]. In this respect, it can be expected to have a large-scale effect on policy and industry [74].

On the other hand, the vagueness pointed out by Gergeson et al. [74] may, ironically, lead to protecting and intensifying the dominant growth model and forms of natural resource extraction, as the concept of green economy was originally created as a reaction to global environmental and economic crises resulting from these very processes [10]. Wanner, for one, argues that the discourse on green economy/growth is just an extension of the sustainable development discourse with the differentiation that it is mainly focused on ensuring the sustainability of economic growth [16]. There is a fear that green economy interpreted as free market environmentalism in the Global South only defends the existing inequitable and ecologically damaging growth patterns while using environmental discourses to legitimize big infrastructure projects, such as dams and intensive commercial agriculture [10]. While the rhetoric in the green economy plans may be promising, the indicators reveal otherwise; e.g., in the Lao PDR, the indicators of the agriculture sector are set for intensified agriculture (ton/hectare maize and rice production) lacking indicators for other targets, such as the promotion of "clean agricultural production (organic farming)" [34]. This kind of selection of indicators reflects the conceptualization of green growth and indicates the prioritization of targets in national strategies.

Similar concerns can be raised about how the strategies aim to improve social issues. According to Vazquez-Brust et al., efficient transformation to improve social inclusiveness can take place only if strong equity-promoting mechanisms are included, such as in the case of South Korea [4]. In the national green economy strategies of Cambodia and the Lao PDR, poverty reduction is among the overall goals, and a variety of issues related to social sustainability are discussed, but clear frameworks and measurable priority targets for them are far fewer than in many other areas. The Lao PDR's strategy sets targets and indicators for reduction of poverty and inequality but not mechanisms for achieving these impacts. The targets set by the Cambodian NSPGG provide guidance, but the detailed action plans, instruments, policy lines, indicators, and monitoring and evaluation plans are to be determined by the respective ministries and other authorities. This may be the most appropriate order as it decreases the donor encroachment on the sovereignty of the countries. However, as for now, the green growth documents read as being reliant on the belief that economic growth will trickle down to the wider public and that markets will intuitively generate solutions for social problems. This is especially evident in the policy documents of the Lao PDR [33,34]. We want to emphasize, keeping in mind the following stages where the detailed distributive policies are decided, that this introduces one of the greatest pitfalls of the strategies in their attempt to balance the economic, social, and environmental aspects. It depends greatly on the development model of a country and the distributive policies used, how much natural resources (and associated emissions) are needed to achieve an acceptable level of social welfare indicators [77]. Arguably, this consideration should be the basis for any national green economy planning. 


\subsection{Prospects for the National Implementation of International Green Economy Agenda?}

For many LDC's, green growth presents an opportunity to continue receiving foreign development funding [10]. This is also stated in the draft strategy of the Lao PDR and brought up by interviewees in Cambodia [34]. The strong influence of donor agendas can be seen in the policies the national green growth strategies propose. What cannot be seen, however, are the financing commitments from the donors to put the concept in practice. The critical point to observe is how the green economy strategies are positioned in relation to other national and sectoral development plans, especially in cases of contradictory interests between economic gains versus most sustainable options. As seen above, when it comes to specific questions where trade-offs are inevitable, such as development of fossil power, the national strategies still seem to accommodate all. While the green economy strategies may use the language of "clean" and "green", the examination of indicators and national and sectoral strategies reveals that the direction of the energy sector remains heavily dependent on foreign direct investments in large-scale hydropower and fossil fuel-based generation in both Cambodia and the Lao PDR.

This raises another question, and a topic for further research, about the power balance between the international players that influence the national policies of the LDCs. For example, the net inflows of foreign direct investment (FDI) made up over 12\% of the GDP of Cambodia in 2018 and $7 \%-10 \%$ of the GDP of the Lao PDR in 2017-2018 [78]. These investments are mainly targeted to hydro and coal power, mining, concession forestry and agriculture, with countries including China, South Korea, Vietnam, and Malaysia as the biggest investors [23]. A good example of the Chinese presence in Cambodia and the Lao PDR is the Belt and Road Initiative channelling investments to infrastructure (such as dams and China-Laos Railway [79]), special economic zones and economic land concessions [80]. In this context, we can argue that it is urgent that the countries include strong guidelines and steering mechanisms for energy and forestry sectors, and make them as priorities in their green economy strategies since these sectors dominate FDI in both countries.

The concern, based on our analysis, is the capability of the states to fulfil the promise of a strong leading role in green economy. For example, in the current World Bank support for the Lao PDR, we may see similar patterns as in the earlier NT2 project, in the ways in which the World Bank attempts to work through and encourage state-initiated policy changes, such as impact assessment. Whether these changes will in fact be operationalised this time, depends heavily on the interest of the state. The institutional barriers among the different state institutions that our interviewees brought up, and the lack of financing (domestic or international) may create significant barriers and indicate reluctance to implement them. It is difficult to draw any conclusions on the definition of green economy in the Lao PDR and the road the country is likely to take, as the whole process so far has been co-produced with, and strongly influenced by, the World Bank. Moreover, to be able to analyse the effects and implications of the green economy policies in detail (especially in Cambodia where its concretization has been left to the sectoral authorities), sector-based strategy papers are crucial, although the capacities of sectoral authorities should also be considered especially in the light of the amount of international technical assistance they typically receive.

The limited state commitment to the implementation of green economy is illustrated in three aspects in both countries. Firstly, the strong involvement of the World Bank as the funder of the national strategy work with minimal state funding forces us to see the national strategies more as donor "wish lists" than actual national commitments. This concern is highlighted also by the inadequate mainstreaming of the targets in other national development plans or (in the case of Cambodia) setting up a monitoring and evaluation system for the national green growth strategies. Secondly, the continuing institutional obstacles and lack of state funding and coordination that our informants spoke of could imply reluctance to fully implement green economy across sectors. Rather, green economy development may remain a field of competition between state institutions. Thirdly, the required legislative changes needed for the sufficient regulation of investments have proceeded slowly even though much of the promise of green economy lays on them. 


\section{Conclusions}

Green economy is framed as an opportunity for LDCs to boost their economy and create employment by developing natural resource-based sectors in an environmentally and socially sustainable manner [17]. In this paper, we have looked at how these ideals translate into national level policies by examining the case of Cambodia and the Lao PDR. The forms in which green economy is defined in the national strategies can be seen within the historical context of power struggles over natural resources management, and the strong influence of international development organizations on one hand, and the foreign investors on the other. In the attempt to raise the countries from LDCs to middle-income countries, the green economy strategies of both Cambodia and the Lao PDR emphasise economic growth over the consideration of environmental and social aspects. This is evident in the absence of strong policies for improving social inclusiveness and phasing out, or at least limiting, the most ecologically harmful industries. Our analysis shows that, despite the search for synergies, at the sectoral level there are still many unaddressed trade-offs. In the energy sector, large-scale hydropower, and coal power are incorporated in the green economy discourse despite their environmentally and socially harmful impacts. In comparison, the targets and actions for the development of more sustainable energy options are modest. In the forest sector, the ambitious forest cover targets are missing funds for implementation, the additional concern being the reliance on mechanisms such as the REDD+, which has not proven to be efficient in forest protection nor does it guarantee a just treatment of local communities. New forest classifications in both countries, including categories from protection to production forests may open new tensions between companies, communities, and forest conservation goals. To avoid re-enforcing the inequitable and ecologically damaging growth pattern of today, the increased use of natural resources should be matched with strong policies to both limit the environmental impacts and to ensure the rights of local communities and distributive impacts which, to date, is lacking in both countries. The capacities and willingness of the states to confront these difficult questions and implement the regulatory measures to control environmental and social impacts define whether we will see a real transition taking place in Cambodia and the Lao PDR.

When the national green economy policies are further developed, our recommendation is to focus on creating enabling legal, regulatory and policy frameworks for green economy. Based on our review, a central challenge is to ensure the capacity of line ministries in setting up a structured system of overseeing the planning, implementation, monitoring, and evaluation of green economy projects, and making all targets visible and measurable, which they currently are only for a handful of targets. Quality of investments should be improved with incentives and regulated with proper environmental and social safeguards. This also entails maximising the domestic economic value added, thus promoting local employment and social benefits including their distributive impacts. At the level of enforcement, sufficient capacity should be ensured at regional and national government bodies (including line ministries) who oversee investments and enforcement of environmental and social safeguard mechanisms. The role of ministries is crucial in analysing and prioritising sustainable options in industries and economic activities over the long term, including phasing out non-desirable industries. In the short term, promoting resource efficiency and savings within the current economic structure would reduce economic losses. Finally, in order to contribute to a large-scale transition, development partners have the responsibility to provide green economy related funding where ODA is fully aligned with the LDC's (such as the Lao PDR's and Cambodia's) own national socio-economic development priorities and plans.

Author Contributions: Conceptualization M.V., M.K., N.V., M.B.D.; Methodology (Key informant interviews and desk review and discourse analysis), M.V., M.K., N.V., M.B.D., J.L., T.T., N.J.H., Investigation, analysis and writing, review and editing M.V., M.K., N.V., M.B.D., J.L., T.T., K.P., J.K.-o., E.C., N.J.H. All authors have read and agreed to the published version of the manuscript.

Funding: This research was funded by the Academy of Finland under Development Research funding instrument for research project number 277182 "Green Economy Transitions in the Least Developed Countries (GET-LDC)". 
Conflicts of Interest: The authors declare no conflict of interest and the funders had no role in the design of the study; in the collection, analyses, or interpretation of data; in the writing of the manuscript, or in the decision to publish the results.

\section{References}

1. United Nations Environment Programme (UNEP). Towards a GREEN Economy. Pathways to Sustainable Development and Poverty Eradication. A Synthesis for Policy Makers. 2011. Available online: https: //sustainabledevelopment.un.org/content/documents/126GER_synthesis_en.pdf (accessed on 8 January 2018).

2. World Commission on Environment and Development. Our Common Future; Oxford University Press: Oxford, UK, 1987.

3. Pearce, D.; Markandya, A.; Barbier, E. Blueprint for a Green Economy; Earthscan: London, UK, 1989.

4. Vazquez-Brust, D.; Smith, A.M.; Sarkis, J. Managing the transition to critical green growth: The "Green Growth State". Futures 2014, 64, 38-50. [CrossRef]

5. Elliott, L. Shades of green in East Asia: The impact of financial crises on the environment. Contemp. Politics 2011, 17, 167-183. [CrossRef]

6. Economic and Social Commission for Asia and the Pacific. Green Growth at a Glance. The Way Forward for Asia and the Pacific; United National Publications: Bangkok, Thailand, 2006.

7. Economic and Social Commission for Asia and the Pacific. Sustainable Infrastructure in Asia: Overview and Proceedings of the Seoul Initiative Policy Forum on Sustainable Infrastructure; United National Publications: Bangkok, Thailand, 2007.

8. GGGI. How We Work. Available online: http://gggi.org/how-we-work/ (accessed on 5 April 2018).

9. The World Bank. Inclusive Green Growth: The Pathway to Sustainable Development; World Bank: Washington, DC, USA, 2012.

10. Death, C. Four discourses of the green economy in the global South. Third World Q. 2015, 36, 2207-2224. [CrossRef]

11. Büscher, B.; Fletcher, R. Accumulation by Conservation. New Political Econ. 2015, 20, 273-298. [CrossRef]

12. D'Amato, D.; Droste, N.; Allen, B.; Kettunen, M.; Lähtinen, K.; Korhonen, J.; Leskinen, P.; Matthies, B.D.; Toppinen, A. Green, circular, bio economy: A comparative analysis of sustainability avenues. J. Clean. Prod. 2017, 168, 716-734. [CrossRef]

13. Dittrich, M.; Giljum, S.; Lutter, S.; Poolzin, C. Green Economies around the World. Implications of Resource Use for Development and the Environment. Available online: https:/www.boell.de/sites/default/files/ 201207_green_economies_around_the_world.pdf (accessed on 8 January 2020).

14. Schandla, H.; Hatfield-Doddsa, S.; Wiedmann, T.; Geschked, A.; Caie, Y.; Westa, J.; Newthe, D.; Baynesa, T.; Lenzend, M.; Owenf, A. Decoupling Global Environmental Pressure and Economic Growth: Scenarios for energy use, materials use and carbon emissions. J. Clean. Prod. 2016, 132, 45-56. [CrossRef]

15. United Nations Environment Programme (UNEP). Resource Efficiency: Potential and Economic Implications. A Report from the International Resource Panel; Ekins, P., Hughes, N., Eds.; United Nations Environment Programme: Nairobi, Kenya, 2017.

16. Wanner, T. The New 'Passive Revolution' of the Green Economy and Growth Discourse: Maintaining the 'Sustainable Development' of Neoliberal Capitalism. New Political Econ. 2014, 20, 21-41. [CrossRef]

17. UNEP; UNCTAD; UN-OHRILLS. Why Green Economy Matters for Least Developed Countries. Available online: https://unctad.org/en/Docs/unep_unctad_un-ohrlls_en.pdf (accessed on 8 January 2018).

18. Kurauchi, Y.; La Vina, A.; Badenoch, N.; Fransen, L. Decentralization of Natural Resources Management. Lessons from Southeast Asia: Case Studies under REPSI; World Resources Institute: Washington, DC, USA, 2006.

19. Schoenweger, O.; Üllenberg, A. Foreign Direct Investment (FDI) in Land in the Lao PDR; Deutsche Gesellschaft für Technische Zusammenarbeit (GTZ): Eschborn, Germany, 2009.

20. Barney, K. Laos and the making of 'relational' resource frontier. Geogr. J. 2009, 175, 146-159. [CrossRef]

21. Käkönen, M.; Kaisti, H. The World Bank, Laos and Renewable Energy Revolution in the Making: Challenges in Alleviating Poverty and Mitigating Climate Change. Forum Dev Stud. 2012, 39, 159-184. [CrossRef]

22. Mekong River Commission. Study on Sustainable Management and Development of the Mekong River Including Impacts of Mainstream Hydropower Projects. Available online: http://www.mrcmekong.org/assets/ Publications/Council-Study/Key-findings-of-the-Council-Study_26-Nov-18_Revised-4-Jan-19.pdf (accessed on 6 January 2020). 
23. Guttal, S.; Chrek, S. An Overview of Large-Scale Investments in the Mekong Region; Focus on the Global South: Bangkok, Thailand, 2016.

24. Hecht, J.S.; Lacombe, G.; Arias, M.E.; Thanh, D.; Piman, T. Hydropower dams of the Mekong River basin: A review of their hydrological impacts. J. Hydrol. 2019, 568, 285-300. [CrossRef]

25. Käkönen, M.; Molle, F.; Foran, T. (Eds.) Contested Waterscapes in the Mekong Region: Hydropower, Livelihoods and Governance; Earthscan: London, UK, 2009.

26. Yasmi, Y.; Durst, P.; Ul Haq, R.; Broadhead, J. Forest Change in the Greater Mekong Subregion (GMS): An Overview of Negative and Positive Drivers; The Food and Agriculture Organization of the United Nations (FAO): Bangkok, Thailand, 2017.

27. About REDD+. Available online: http://www.unredd.net/about/what-is-redd-plus.html (accessed on 12 February 2018).

28. What is the EU FLEGT Action Plan? Available online: http://www.euflegt.efi.int/flegt-action-plan (accessed on 13 February 2018).

29. National Council on Green Growth. The National Policy on Green Growth 2013-2030. Royal Government of Cambodia 2013. Available online: https://policy.asiapacificenergy.org/sites/default/files/national-policy-ongreen-growth_2013.pdf (accessed on 17 April 2019).

30. National Council on Green Growth. The National Strategic Plan on Green Growth 2013-2030. Royal Government of Cambodia 2013. Available online: https://www.greengrowthknowledge.org/sites/default/ files/downloads/policy-database/CAMBODIA)\%20National\%20Strategic\%20Plan\%20on\%20Green \% 20Growth\%202013--2030.pdf (accessed on 17 April 2019).

31. Royal Government of Cambodia. The National Strategic Development Plan 2014-2018. Royal Government of Cambodia, Phnom Penh 2014. Available online: https:/www.ilo.org/wcmsp5/groups/public/---asia/---robangkok/---sro-bangkok/documents/genericdocument/wcms_364549.pdf (accessed on 17 April 2019).

32. Ministry of Planning and Investment (Lao PDR). 8th Five-Year National Socio-Economic Development Plan (2016-2020); Ministry of Planning and investment: Vientiane, Laos, 2016.

33. The World Bank. Lao People's Democratic Republic: First Programmatic Green Growth Development Policy Operation; The World Bank: Washington, DC, USA, 2017.

34. National Economic Research Institute. First Draft: The National Green Growth Strategy of the Lao PDR; National Economic Research Institute: Vientiane, Laos, 2018.

35. Giddens, A. The Constitution of the Society: Outline of the Theory of Structuration; University of California Press: Berkeley, CA, USA, 1984.

36. Bryant, R.L.; Bailey, S. Third World Political Ecology; Routledge: London, UK; New York, NY, USA, 1997.

37. Hak, M. A Design of Low Carbon Development Action towards 2050 in Cambodia. Ph.D. Thesis, Kyoto University, Kyoto, Japan, 24 September 2015.

38. Ministry of Environment. Climate Change Action Plan (CCAP) 2016-2018; Royal Government of Cambodia: Phnom Penh, Cambodia, 2016.

39. General Secretariat of the National Council for Sustainable Development. NCSD Structure. Available online: http://www.camclimate.org.kh/en/policies/ncsd-structure.html (accessed on 19 March 2019).

40. Royal Government of Cambodia. National Strategic Development Plan 2019-2023; Royal Government of Cambodia: Phnom Penh, Cambodia, 2019. (In Khmer)

41. World Bank. Sustainable Energy for All Database. Available online: https://data.worldbank.org/indicator/ EG.ELC.ACCS.ZS?locations=KH (accessed on 17 April 2019).

42. Fawthorp, T. Leaked Report Warns Cambodia's Biggest Dams could 'Literally Kill' Mekong River. The Guardian. 2018. Available online: https://www.theguardian.com/environment/2018/may/16/leakedreport-warns-cambodias-biggest-dam-could-literally-kill-mekong-river (accessed on 19 April 2019).

43. Siciliano, G.; Urban, F.; Kim, S.; Lonn, P.D. Hydropower, social priorities and the rural-urban development divide: The case of large dams in Cambodia. Energy Policy 2015, 86, 273-285. [CrossRef]

44. Men, P.; Thun, V.; Yin, S.; Lebel, L. Benefit sharing from Kamchay and Lower Sesan 2 hydropower watersheds in Cambodia. Water Resour. Rural. Dev. 2014, 4, 40-53. [CrossRef]

45. World Wide Fund for Nature (WWF); Intelligent Energy Systems (IES); Mekong Strategic Partners. Power Sector Vision. Towards 100\% Renenwable Electricity by 2050, Greater Mekong Region, Cambodia Report. WWF Reports. 2016. Available online: https://d2ouvy59p0dg6k.cloudfront.net/downloads/power_sector_ vision_2016.pdf (accessed on 10 January 2020). 
46. Asian Development Bank. Renewable Energy Developments and Potential in the Greater Mekong Subregion; Asian Development Bank: Mandaluyong City, Philippines, 2015.

47. De Ferranti, R.; Fulbrook, D.; McGinley, J.; Higgins, S. Switching On: Cambodia's Path to Sustainable Energy Security; Mekong Strategic Partners: Phnom Penh, Cambodia, 2016.

48. Royal Government of Cambodia. National Forest Programme 2010-2029; Royal Government of Cambodia: Phnom Penh, Cambodia, 2010. Available online: http://www.cdc-crdb.gov.kh/cdc/documents/Sector_ Strategy/6_Forestry_Reform/National_Forest_Programme_2010_2029_Eng.pdf (accessed on 24 April 2019).

49. Royal Government of Cambodia. Law on Forestry; Royal Government of Cambodia: Phnom Penh, Cambodia, 2003; Available online: http://extwprlegs1.fao.org/docs/pdf/cam50411.pdf (accessed on 24 April 2019).

50. Cambodia's Forests are Disappearing. Available online: https://earthobservatory.nasa.gov/images/89413/ cambodias-forests-are-disappearing (accessed on 17 April 2019).

51. Davis, K.; Yu, K.; Rulli, M.; Pichdara, L.; D’Odorico, P. Accelerated deforestation driven by large-scale land acquisitions in Cambodia. Nat. Geosci. 2015, 8, 772-775. [CrossRef]

52. Beresford, N.; Saiko-Jensen, M. Why Care about Cambodia's Forests? The Phnom Penh Post. 2018. Available online: https://www.phnompenhpost.com/opinion/why-care-about-cambodias-forests (accessed on 9 June 2020).

53. Open Development Cambodia. Forest Policy and Administration. Available online: https:// opendevelopmentcambodia.net/topics/forest-policy-and-administration/ (accessed on 9 June 2020).

54. Terme, R.A.; Kharas, H. Lao PDR Gets Ready for NT2. In Doing a Dam Better: The Lao People's Democratic Republic and the Story of Nam Theun 2; Porter, I., Shivakumar, J., Eds.; The World Bank: Washington, DC, USA, 2011; pp. 33-50.

55. Singh, S. Nam Theun 2 and the Transformation of Institutions and Public Debate in Laos. In Dead in the water: Global Lessons from the World Bank's Model Hydropower Project in Laos; Shoemaker, B., Robichaud, W., Eds.; University of Wisconsin Press: Madison, WI, USA, 2018; pp. 217-241.

56. Dwyer, M.B.; Ingalls, M. REDD+ at the Crossroads: Choises and Tradeoffs for 2015-2020 in Laos; Working paper 179; CIFOR: Bogor, Indonesia, 2015.

57. Schönweger, O.; Heinimann, A.; Epprecht, M.; Lu, J.; Thalongsengchanh, P. Concessions and Leases in the Lao PDR: Taking Stock of Land Investments; Centre for Development and Environment (CDE), University of Bern, Bern and Vientiane: Geographica, Bernensia, 2012.

58. Dwyer, M.B. Territorial Affairs: Turning Battlefields into Marketplaces in Postwar Laos. Ph.D. Thesis, University of California, Berkeley, CA, USA, 2011.

59. Growth on Track Expected for Lao PDR in 2017 and 2018-ADB. Available online: https://www.adb.org/ news/growth-track-expected-lao-pdr-2017-and-2018-adb (accessed on 19 May 2018).

60. Pillai, G.M. Lao PDR National Sustainable Energy Strategy Report on Enabling Environment and Technology Innovation Ecosystem for Affordable Sustainable Energy Options; Asian and Pacific Centre for Transfer of Technology (APCTT) of the Economic and Social Commission for Asia and the Pacific (UNESCAP): New Delhi, India, 2014.

61. United National Development Program. NAMA for the Renewable Energy Sector of Lao PDR; UNDP: New York, NY, USA, 2016.

62. Laos-Access to Electricity. Available online: http://web.archive.org/web/20180625072705/https://tradingeconomics. com/laos/access-to-electricity-percent-of-total-population-wb-data.html (accessed on 30 October 2018).

63. Thoummavongsa, S. Renewable Energy Market Development in Lao PDR-Opportunitues for investment. ASEAN Sustainable Energy Week, Bangkok, Thailand, 9 June 2017. Available online: http://www.entechpollutec-asia.com/Portals/0/conference/EEPO/EPPO\%20Vietnam\%20(MR216--217) \%20Presentation\%20Mr.\%20Sermkham-Laos\%20Presentation.pdf (accessed on 10 October 2018).

64. Räsänen, T.A.; Varis, O.; Scherer, L.; Kummu, M. Greenhouse gas emissions of hydropower in the Mekong River Basin. Environ. Res. Lett. 2018, 13, 034030. [CrossRef]

65. Ziv, G.; Baran, E.; Nam, S.; Rodríguez-Iturbe, I.; Levin, S.A. Trading-off fish biodiversity, food security, and hydropower in the Mekong River Basin. Proc. Natl. Acad. Sci. USA 2012, 109, 5609-5614. [CrossRef]

66. Intralawan, A.; Wood, D.; Frankel, R. Economic, Environmental and Social Impacts of Hydropower Development in the Lower Mekong Basin; Working Paper; Natural Resources and Environmental Management Research and Training Center Mae Fah Luang University: Chiang Rai, Thailand, 2015.

67. Smirnov, D. Assessment of Scope of Illegal Logging in Laos and Associated Transboundary Timber Trade; World Wide Fund for Nature (WWF): Gland, Switzerland, 2015; unpublished draft for internal use. 
68. Barney, K.; van der Meer Simo, A. Forest Plantations and Smallholder Livelihoods: Evidence from Community Case Studies in Lao PDR; ACIAR Project Working Paper 5; Australian National University: Canberra, Australia, 2019.

69. IRENA; ACE. Renewable Energy Outlook for ASEAN: A REmap Analysis; International Renewable Energy Agency (IRENA), Abu Dhabi and ASEAN Centre for Energy (ACE): Jakarta, Indonesia, 2016.

70. Ministry of Energy and Mines, Lao PDR. Lao PDR Energy Statistics 2018; Economic Research Institute for ASEAN and East Asia: Jakarta, Indonesia, 2018.

71. Kamal, U. Joint Crediting Mechanism in Cambodia. East Asia Low Carbon Growth Dialogue, Paris, France, 7 December 2015. Available online: https://www.mofa.go.jp/files/000118241.pdf (accessed on 20 January 2020).

72. Cabello, J.; Gilbertson, T. A colonial mechanism to enclose lands: A critical review of two REDD+-focused special issues. Ephemera 2012, 12, 162-180.

73. Olsen, K.H. The clean development mechanism's contribution to sustainable development: A review of the literature. Clim. Change 2007, 84, 59-73. [CrossRef]

74. Georgeson, L.; Maslin, M.; Poessinouw, M. The global green economy: A review of concepts, definitions, measurement methodologies and their interactions. Geogr. Environ. 2017, 4, e00036. [CrossRef]

75. Borel-Saladin, J.M.; Turok, I.N. The Green Economy: Incremental Change or Transformation? Environ. Pol. Gov. 2013, 23, 209-220. [CrossRef]

76. Is 'Green Growth' Just the Latest Development Fad? Available online: http://www.devpolicy.org/is-greengrowth-just-the-latest-development-fad-20140721/ (accessed on 17 April 2019).

77. Hickel, J. Is it possible to achieve a good life for all within planetary boundaries? Third World Q. 2019, 40, 18-35. [CrossRef]

78. Foreign Direct Investment, Net Inflows (\% of GDP)—Cambodia, Vietnam, Myanmar, Lao PDR, Thailand. Available online: https://data.worldbank.org/indicator/BX.KLT.DINV.WD.GD.ZS?locations=KH-VN-MMLA-TH\&page $=4$ (accessed on 31 January 2020).

79. Rowedder, S. Railroading land-linked Laos: China's regional profits, Laos' domestic costs? Eurasian Geogr. Econ. 2020, 61, 152-161. [CrossRef]

80. Yamada, T.S. Cambodia's Changing Landscape: Rhetoric and Reality. In China and Southeast Asia in the Xi Jinping Era; Lin, A.C.-H., Cibulka, F., Eds.; Lexington Books: London, UK, 2019; pp. 65-85.

(C) 2020 by the authors. Licensee MDPI, Basel, Switzerland. This article is an open access article distributed under the terms and conditions of the Creative Commons Attribution (CC BY) license (http://creativecommons.org/licenses/by/4.0/). 